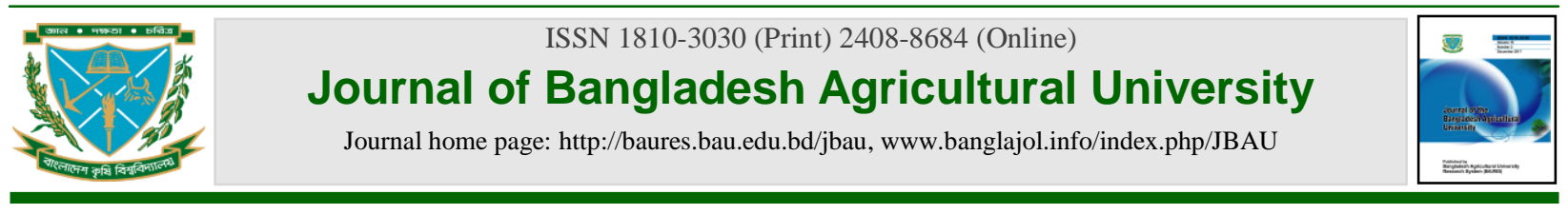

\title{
Varietal preference of okra jassid, Amrasca devastans (Dist.) under field condition of Bangladesh
}

\author{
M. N. Sultana, M. M. Uddin, M. Ahmad and S. M. Adnan \\ Department of Entomology, Bangladesh Agricultural University Mymensingh-2202, Bangladesh
}

\begin{tabular}{|c|c|}
\hline ARTICLE INFO & Abstract \\
\hline $\begin{array}{l}\text { Article history: } \\
\text { Received: } 29 \text { October } 2017 \\
\text { Accepted: } 04 \text { December } 2017\end{array}$ & $\begin{array}{l}\text { An experiment was conducted in the Field Laboratory, Department of Entomology, (BAU), Mymensingh } \\
\text { on the varietal preference of okra jassid, Amrasca devastans (Dist.) using } 14 \text { okra varieties viz. } F_{1} \\
\text { Tamanna, Hybrid Okra Gunyon, Okra } F_{1} \text { Green Soft, OK 285, Okra } F_{1} \text { Green Star 33, } F_{1} \text { Hybrid Fresh } \\
\text { Power, } F_{1} \text { Hybrid Sarosh 3, Hybrid Okra (MDR), Okra Nabil, BARI-1 (Samrat), Hybrid Chamak and }\end{array}$ \\
\hline $\begin{array}{l}\text { Keywords: } \\
\text { Variety, Preference, Okra, Jassid, } \\
\text { Amrasca devastans }\end{array}$ & $\begin{array}{l}\text { Kolatia were the least preferred by jassid. Five varieties viz. Okra Nabil, Hybrid Okra (MDR), } F_{1} \text { Hybrid } \\
\text { Fresh Power, Local variety, and OK } 285 \text { were comparatively highly preferred and rest of the six varieties } \\
\text { viz. Okra } F_{1} \text { Green Star 33, BARI-1 (Samrat), } F_{1} \text { Tamanna, } F_{1} \text { Hybrid Sarosh } 3 \text {, Hybrid Okra Gunyon, and }\end{array}$ \\
\hline $\begin{array}{l}\text { Correspondence: } \\
\text { M. M. Uddin } \\
\text { (mahir@bau.edu.bd) }\end{array}$ & $\begin{array}{l}\text { Okra } F_{1} \text { Green Soft were moderately preferred by jassid. This variation of preference of okra jassid might } \\
\text { be due to different morphological and physiological characters of selected varieties. It could be concluded } \\
\text { that comparatively resistant varieties selected from the present study might be incorporated to develop of } \\
\text { IPM package for jassid. }\end{array}$ \\
\hline
\end{tabular}

\section{Introduction}

Okra (Abelmoschus esculentus L.) is one of the most common summer vegetables grown in Bangladesh. It is also known as lady's finger and locally called "Dharos" or "Vendi" or "Gumbo" which belongs to the family Malvaceae. Okra (Abelmoschus esculentus L.) is an economically important vegetable crop grown in tropical and sub-tropical parts of the world (Arapitsas, 2008; Saifullah and Rabbani, 2009). It is also well distributed in the Indian subcontinent and East Asia (Kochhar, 1986). In Bangladesh, substantial amount of okra is produced each year. In 2009-10, 42 thousand metric tons of okra was produced from 10.20 thousand hectares of land (BBS, 2011). Okra contributes greatly in filling up the gaps when the market suffers from adequate supply of both winter and summer vegetables. Okra contains carbohydrate, proteins and vitamin $\mathrm{C}$ in large quantities (Dilruba et al., 2009), and plays a vital role in human diet (Kahlon et al., 2007; Saifullah and Rabbani, 2009). The immature pods are the edible part of this plant and are consumed as a vegetable. Fruits can be boiled, fried or cooked (Akintoye et al., 2011). Due to its high iodine contents, the 'okra' fruit is considered to be useful for the control of goiter. Okra production in Bangladesh is affected by many factors. Critical analysis for such low productivity revealed that major portion of okra produced is being damaged by dread insect pests. Several insect pests have so far been recorded to attack okra like jassid, aphid, whitefly, leaf roller and shoot and fruit borer. Among sucking insect pest jassid, Amrasca devastans is the most serious (El-Tom, 1987; Singh et al., 1993; Dhandapani et al., 2003). It causes a great damage by sucking the plant sap resulting $30-40 \%$ crop yield loss. Both the adult and nymph suck the cell sap from the leaves. Damaged leaves curl at the edges and develop brown, dead-spots with a yellow halo at their edges.

In Bangladesh for the management of jassid only chemical insecticides are used. But chemical insecticides have a highly toxic effect. Therefore, there is an urgent need to develop environment friendly alternative methods to manage this pest. In this case, resistant variety is one of the most cost-effective and safe method for this pest. A resistant variety can provide a base on which to construct an integrated control system (Gallun et al., 1975) and may be most fruitful when used in connection with other methods of control. Resistant variety screening is seen to be a sustainable approach to pest management and varietals trials of different okra plants to jassid is essential. In Bangladesh limited number of research studies has so far been done on the varietal preference of okra jassid. To develop a suitable management strategy it is necessary to know the varietal preference of this pest. Considering the above points the present study has been conducted to screen out resistant variety(s) for okra jassid.

\section{Materials and Methods}

The experiment on the varietal preference of okra jassid, Amrsaca devastans was conducted in Entomology Field Laboratory of BAU, Mymensingh during March to June, 2014 to find out resistant varietiesto jassid, Amrasca devastans using 14 varieties of okra (Okra varieties viz. Arka Anamika, $\mathrm{F}_{1}$ Tamanna, Hybrid Okra Gunyon, Okra 
$F_{1}$ Green Soft, Kolatia, OK 285, Okra F1 Green Star 33, F1 Hybrid Fresh Power, F1 Hybrid Sarosh 3, Hybrid Okra MDR, Okra Nabil, BARI 1 (Samrat), Hybrid Chamak, and Local variety). At first, soil of the experimental field was prepared thoroughly by ploughing and cross ploughing followed by laddering to have a good tilth. The plots were raised by $10 \mathrm{~cm}$ from the soil surface keeping the drain around the plots. Recommended doses of manure (Cowdung @ $15 \mathrm{t} / \mathrm{ha}$ ) and fertilizers (urea $150 \mathrm{Kg} / \mathrm{ha}$, TSP $100 \mathrm{Kg} / \mathrm{ha}$, MoP $150 \mathrm{KG} / \mathrm{ha}$ ) were used (Rashid, 1999). Full amount of Cowdung and TSP, half of MoP were applied basally one week before sowing and well mixed with soil. The rest half of $\mathrm{MoP}$ and urea were applied in three equal installments as top dressing at 25 days after sowing (DAS), flower initiation stage and fruit initiation stage.

Seeds were collected from Dhaka and Mymensingh local market. Seeds were sown on $1^{\text {st }}$ week of March in the field. Seeds of okra cultivars were soaked in water for 12 hours and sown directly in the pits. Three seeds were sown in each pit maintaining line to line distance and plant to plant distance $40 \mathrm{~cm}$. Seeds were covered with loose soil. The plots were watered just after sowing. Gap filling was done by transplanting seedlings from the stock. Intercultural operations such as irrigation, weeding, thinning, staking and other operations were done throughout the cropping season for proper growth and development of the plants. Supplementary irrigation was applied at an interval of 23 days. Weeding was done as and when necessary.

These plants were used for the varietal preference experiment. The experiment was designed in RCBD with three replications of each treatment in the field. The whole experimental field was $18 \mathrm{~m}$ length and $16 \mathrm{~m}$ breadth which was divided into 3 equal blocks and each block was divided into fourteen plots. Block to block distance was $0.5 \mathrm{~m}$. Every unit plot had 4 rows with 5 plants at each row. The total number of plants per plot was 20.The varietal preference of okra jassid at different stages of the plants was determined by counting the number of total egg, nymph, adult, and curl leaf at vegetative stage. Data were collected at every 7 days interval. All the data were analyzed statistically following the computer package MSTAT-C programming. The mean differences among the treatments were adjudged as per test with Duncan's Multiple Range Test (DMRT) and Least Significant Difference (LSD) when necessary.

\section{Results and Discussion}

\section{Varietal Preference of Okra Jassid}

\section{Mean number of eggs per plant}

The eggs laid by okra jassid on the plants were counted and then mean number of eggs per plant was found out at different days after sowing (DAS). This counting was performed using the selected varieties. The result showed that the mean number of eggs/plant varied significantly among the varieties tested (Table 1). At 56 DAS, the lowest mean number of eggs per plant was found in variety Hybrid Chamak (9.33) followed by Kolatia (10.67) and Arka Anamika (11.33). The highest number of eggs per plant was found in the variety Okra Nabil (31.33) followed by Hybrid Okra (MDR) (27.33), Local variety (26.33) and OK 285 (24.67). The data also revealed that average mean number of eggs was found on the plants of six varieties viz. Hybrid Okra Gunyon (18.33), Okra $F_{1}$ Green Star 33 (17.33), $F_{1}$ Tamanna (16.67), BARI-1 (Samrat) (16.33), and Okra $\mathrm{F}_{1}$ Green Soft (15.67\%). The number of eggs per plant at 63 DAS was the lowest in Hybrid Chamak (7.67) followed by Kolatia (8.00) and Arka Anamika (8.333). On the other hand, the highest number of egg per plant was found in the variety Okra Nabil (26.33) followed by Hybrid Okra (MDR) (24.00), F 1 Hybrid Fresh Power (23.33), Local variety (23.6) and OK 285 (21.00). The data also revealed that average mean number of eggs was found on the plants of rest of the six varieties similar to 56 DAS.

At 70 DAS the mean number of eggs per plant was the highest in case of variety Okra Nabil (25.33) followed by Hybrid Okra (MDR) (22.33), OK 285 (19.33) and Local variety (18.00). The lowest number of egg was found in Arka Anamika (6.33), Hybrid Chamak (7.333) and Kolatia (7.67). The data also indicated that average mean numbers of eggs were found on the plants of other six varieties. But at 77 DAS, the mean number of eggs per plant was the lowest on the variety Hybrid Chamak (5.67) followed by Kolatia (6.00) and Arka Anamika (6.00). The highest number of eggs per plant was found in the variety Okra Nabil (21.00) followed by Hybrid Okra (MDR) (17.67), OK 285 (17.67), F1Hybrid Fresh Power (17.67) and Local variety (16.33). Similar to 70 DAS the average mean number of eggs were found on the plants of six varieties.

The lowest mean number of eggs per plant was found on Kolatia (3.33) and Hybrid Chamak (3.33) followed by Arka Anamika (5.00) at 84 DAS. But the highest number of eggs per plant was found in the variety Hybrid Fresh Power (14.67), Hybrid Okra (MDR) (14.00), Okra Nabil (13.67), Local variety (12.33) and OK 285 (11.33). The moderate mean number of eggs was found similar to 77 DAS. The mean number of eggs per plant at 91 DAS was the lowest in case of variety Hybrid Chamak (1.667) followed by Arka Anamika (3.667) and Kolatia (4.67). The highest number of eggs per plant was found in the variety Okra Nabil (11.67) and OK 285 (11.67) followed by Hybrid Okra (MDR) (10.33), F1Hybrid Fresh Power (10.33) and Local variety (10.33). The average mean numbers of eggs were similar to 84 DAS.

In case of cumulative mean, the highest number of eggs per plant was recorded in Okra Nabil (21.61) followed 
by Hybrid Okra (MDR) (19.28), $F_{1}$ Hybrid Fresh Power (18.45), Local variety (17.83) and OK 285 (17.61) which indicated the higher preference by jassid. Comparatively higher resistance was showed by three varieties viz. Hybrid Chamak (5.83) Kolatia (6.72) and Arka Anamika (6.78) receiving significantly the lowest number of eggs per plant. The rest of the six varieties were moderately preferred by jassid with the average mean numbers of eggs per plant. The overall preference rank of okra jassid among the 14 varieties tested was in the following order: Okra Nabil> Hybrid Okra (MDR) $>F_{1}$ Hybrid Fresh Power $>$ Local variety $>\mathrm{OK}$ 285>Okra $F_{1}$ Green Star 33>BARI-1 (Samrat)> Hybrid Okra Gunyon $>F_{1}$ Tamanna $>F_{1}$ Hybrid Sarosh 3>Okra $F_{1}$ Green Soft>Arka Anamika> Kolatia >Hybrid Chamak.

Table 1. Mean number of jassid eggs per plant on different okra varieties in the field

\begin{tabular}{|c|c|c|c|c|c|c|c|c|}
\hline \multirow[t]{2}{*}{ Variety } & \multicolumn{7}{|c|}{ Number of eggs/plant } & \multirow{2}{*}{ Rank } \\
\hline & 56 DAS & $63 \mathrm{DAS}$ & 70 DAS & 77 DAS & 84 DAS & $91 \mathrm{DAS}$ & $\begin{array}{c}\text { Cumulative } \\
\text { mean }\end{array}$ & \\
\hline Hybrid Okra (MDR) & $27.33 \mathrm{ab}$ & $24.00 \mathrm{a}$ & $22.33 \mathrm{ab}$ & $17.67 \mathrm{ab}$ & $14.00 \mathrm{a}$ & $10.33 \mathrm{ab}$ & 19.28 & 2 \\
\hline $\mathrm{F}_{1}$ Tamanna & $16.67 \mathrm{cde}$ & $14.33 \mathrm{~d}$ & $14.33 \mathrm{cde}$ & $11.33 \mathrm{bcd}$ & 8.00bce & $6.33 \mathrm{bcd}$ & 11.83 & 9 \\
\hline Hybrid Okra Gunyon & $18.33 \mathrm{bcf}$ & $17.67 \mathrm{bd}$ & $13.33 \mathrm{cdefg}$ & $9.33 \mathrm{~cd}$ & $8.33 \mathrm{bcde}$ & $5.00 \mathrm{bcd}$ & 11.99 & 8 \\
\hline $\mathrm{F}_{1}$ Green Star 33 & $17.33 \mathrm{cde}$ & $14.33 \mathrm{~d}$ & $12.00 \mathrm{e}^{\circ}$ & $13.67 \mathrm{bc}$ & $9.67 \mathrm{bcd}$ & 7.33abcd & 12.39 & 6 \\
\hline Kolatia & $10.67 \mathrm{f}$ & $8.00 \mathrm{ef}$ & $7.67 \mathrm{fgh}$ & $6.00 \mathrm{~d}$ & $3.33 \mathrm{e}$ & $4.67 \mathrm{bcd}$ & 6.72 & 13 \\
\hline OK 285 & $24.67 \mathrm{abc}$ & $21.00 \mathrm{abc}$ & 19.33abcd & $17.67 \mathrm{ab}$ & $11.33 \mathrm{abc}$ & $11.67 \mathrm{a}$ & 17.61 & 5 \\
\hline $\mathrm{F}_{1}$ Green Soft & $15.67 \mathrm{ef}$ & $13.67 \mathrm{de}$ & 11.33 efgh & $9.00 \mathrm{~cd}$ & $8.33 \mathrm{bcde}$ & 7.00abcd & 10.83 & 11 \\
\hline $\mathrm{F}_{1}$ Hybrid Fresh Power & $25.67 \mathrm{abc}$ & $23.33 \mathrm{ab}$ & $20.00 \mathrm{abc}$ & $17.67 \mathrm{ab}$ & $13.67 \mathrm{a}$ & $10.33 \mathrm{ab}$ & 18.45 & 3 \\
\hline $\mathrm{F}_{1}$ Hybrid Sarosh 3 & $16.00 \mathrm{def}$ & $13.33 \mathrm{def}$ & $13.00 \mathrm{de}$ & $9.67 \mathrm{~cd}$ & $6.67 \mathrm{cde}$ & $9.33 \mathrm{abc}$ & 11.33 & 10 \\
\hline Arka Anamika & $11.33 \mathrm{f}$ & $8.33 \mathrm{ef}$ & $6.33 \mathrm{~h}$ & $6.00 \mathrm{~d}$ & $5.00 \mathrm{de}$ & $3.67 \mathrm{~cd}$ & 6.78 & 12 \\
\hline Okra Nabil & $31.33 \mathrm{a}$ & $26.33 \mathrm{a}$ & $25.33 \mathrm{a}$ & $21.00 \mathrm{a}$ & $14.00 \mathrm{a}$ & $11.67 \mathrm{a}$ & 21.61 & 1 \\
\hline BARI-1 (Samrat) & $16.33 d$ & $17.67 \mathrm{bcd}$ & $13.67 \mathrm{cde}$ & $11.33 \mathrm{bcd}$ & $6.67 \mathrm{cde}$ & 7.00abcd & 12.11 & 7 \\
\hline Hybrid Chamak & $9.33 \mathrm{f}$ & $7.667 f$ & $7.333 \mathrm{gh}$ & $5.67 \mathrm{~d}$ & $3.33 \mathrm{e}$ & $1.667 \mathrm{~d}$ & 5.83 & 14 \\
\hline Local variety & $26.33 \mathrm{abc}$ & $23.67 \mathrm{a}$ & $18.00 \mathrm{bcde}$ & $16.33 \mathrm{ab}$ & $12.33 \mathrm{ab}$ & $10.33 \mathrm{ab}$ & 17.83 & 4 \\
\hline $\operatorname{LSD}_{(0.05)}$ & 8.657 & 5.388 & 5.956 & 5.964 & 4.545 & 5.095 & - & \\
\hline $\mathrm{CV}(\%)$ & 27.04 & 19.26 & 24.35 & 28.87 & 30.41 & 39.97 & - & \\
\hline Level of significance & $* * *$ & $* *$ & $* *$ & $* *$ & $* *$ & $* *$ & & \\
\hline
\end{tabular}

Different letters in a column indicate the significant $(\mathrm{p} \leq 0.05)$ difference among the mean number of eggs

The variety Hybrid Chamak differed significantly from all other varieties receiving the lowest number of eggs per plant. At the same time Kolatia, and Arka Anamika also showed outstanding performance. So, it can be concluded that these three varieties were more resistant among the 14 varieties which was indicated by less preference of okra jassid. On the other hand, the highest number of eggs was observed in variety Okra Nabil. Similarly on Hybrid Okra (MDR), $F_{1}$ Hybrid Fresh Power, Local variety, and OK 285 also found higher number of eggs per plant. These varieties were susceptible to jassid infestation and therefore, these were highly preferred by jassid. The rest of the varieties viz. Okra $F_{1}$ Green Star 33 (12.39), BARI-1 (12.11), $F_{1}$ Hybrid Sarosh 3 (11.33), $\mathrm{F}_{1}$ Tamanna (11.83) and Okra $F_{1}$ Green Soft (10.83), were found moderately resistant to jassid infestation. Ullah et al. (2012) worked on five okra varieties viz. Sharmeeli, Pusa Green, Anokhi, Arka Anamika and Sabz Pari. They reported that Arka Anamika was found comparatively less preferred while Anokhi was highly preferred to jassid. This report was partially similar with the present results where Arka Anamika was the least preferred variety among the 14 varieties tested. Kumar and Singh (2002) worked on seven variety of okra and reported that minimum leafhopper population and leaf infestation was observed in the variety Arka Anamika. He also found Arka Anamika as the least preferred and other two varities viz. Anitha and Nandihalli were highly preferred to jassid. Uthamasamy (1986) investigated the preference of A. biguttula biguttula for oviposition, feeding and found that 'okra' A.E. 22 to be less preferred for oviposition and feeding than the susceptible Pusa Swani. $\mathrm{He}$ also reported that the rate of multiplication of leaf hoppers on resistant variety was low as compared to that of the susceptible one. From the above mentioned findings it could be finally concluded that jassid showed the different grades of preference for egg laying among different varieties of okra in the field due to the variation in the resistance level of the varieties.

\section{Mean number of nymphs per plant}

Similar to the eggs the mean number of nymphs per plant varied significantly among 14 okra varieties tested (Table 2). The mean number of nymphs at 56 DAS was the lowest in case of variety Arka Anamika (18.33) followed by Hybrid Chamak (18.67) and Kolatia (20.00) which indicated the least preference to these varieties by jassid. The highest number of nymphs per plant was observed in Okra Nabil (30.33) and Hybrid Okra (MDR) (30.33) followed by OK 285 (27.33), $F_{1}$ Hybrid Fresh Power (25.67) and Local variety (23.33) which indicated 
the higher preference of jassid to these varieties. The moderate mean number of nymphs per plant was recorded in the varieties Okra $F_{1}$ Green Star 33 (20.00), $\mathrm{F}_{1}$ Tamanna ((18.67), BARI-1 Samrat (18.67), $\mathrm{F}_{1}$ Hybrid Sarosh 3(18.33), Hybrid Okra Gunyon (17.67) and Okra $\mathrm{F}_{1}$ Green Soft (17.67). These varieties were moderately preferred by the jassid (Table 2). At 63 DAS the mean number of nymphs was the lowest on Kolatia (10.33) followed by Hybrid Chamak (10.67) and Arka Anamika (11.33). The highest number of nymphs per plant was observed in Okra Nabil (26.33), Hybrid Okra (MDR) (24.67), OK 285 (24.33), $F_{1}$ Hybrid Fresh Power (22.67) and Local variety (22.67). The average mean number of nymphs per plant was recorded in the rest of the varieties which indicated moderately preferred by the jassid.

The lowest mean number of nymphs per plant was on Kolatia (7.66) followed by Hybrid Chamak (7.33) and Arka Anamika (6.33) at 70 DAS. The highest number of nymph per plant was recorded in Okra Nabil (25.33) followed by OK 285 (22.67), Hybrid Okra (MDR)
(19.33), $F_{1}$ Hybrid Fresh Power (18.67) and Local variety (18.00). The medium number of nymphs per plant was recorded in six other varieties. So, these varieties were moderately preferred by the jassid. The mean number of nymphs at 77 DAS was the lowest in case of variety Hybrid Chamak (7.667) followed by Arka Anamika (7.333) and Kolatia (6.667). The highest number of nymph per plant was observed in variety OK 285 (21.67), $F_{1}$ Hybrid Fresh Power (19.00), Okra Nabil (18.33), Hybrid Okra (MDR) (17.33) and Local variety (17.33). The rest of six varieties were moderately preferred by the nymphs of jassid for feeding.

Similar to 70 DAS mean number of nymphs was the lowest on the plants of variety Kolatia (5.33) followed by Hybrid Chamak (5.33) and Arka Anamika (8.66) at 84 DAS. The highest number of nymphs per plant was observed in variety Okra Nabil (14.67) followed by $\mathrm{F}_{1}$ Hybrid Fresh Power (14.33), OK 285 (14.00), Hybrid Okra (MDR) (13.67) and Local variety (13.33). The rest of the varieties had the average mean number of nymphs per plant. Similar results were found at 91 DAS.

Table 2. Mean number of nymphs of okra jassid per plant on different okra varieties in the field

\begin{tabular}{|c|c|c|c|c|c|c|c|c|}
\hline \multirow[t]{2}{*}{ Variety } & \multicolumn{7}{|c|}{ Number of nymphs/plant } & \multirow[b]{2}{*}{ Rank } \\
\hline & 56 DAS & $63 \mathrm{DAS}$ & 70 DAS & 77 DAS & 84 DAS & 91 DAS & $\begin{array}{c}\text { Cumulative } \\
\text { mean }\end{array}$ & \\
\hline Hybrid Okra (MDR) & $30.33 a$ & $24.67 \mathrm{ab}$ & $19.33 \mathrm{ab}$ & $17.33 \mathrm{abc}$ & $15.33 \mathrm{ab}$ & $13.67 \mathrm{a}$ & 20.11 & 2 \\
\hline $\mathrm{F}_{1}$ Tamanna & $18.67 \mathrm{cde}$ & $15.33 \mathrm{cdef}$ & $13.33 \mathrm{~cd}$ & $14.33 \mathrm{bcd}$ & 11.67abcd & $9.00 \mathrm{abc}$ & 13.72 & 11 \\
\hline Hybrid Okra Gunyon & $17.67 \mathrm{cde}$ & $15.33 \mathrm{cdef}$ & $16.33 \mathrm{bc}$ & $13.33 \mathrm{~cd}$ & $12.33 \mathrm{abc}$ & $11.00 \mathrm{ab}$ & 14.33 & 8 \\
\hline $\mathrm{F}_{1}$ Green Star 33 & 20.00bcde & $17.33 \mathrm{bcdef}$ & $14.67 \mathrm{bcd}$ & $12.67 \mathrm{~d}$ & $12.33 \mathrm{abc}$ & $10.67 \mathrm{ab}$ & 14.61 & 7 \\
\hline Kolatia & $12.6 \mathrm{ef}$ & $10.33 \mathrm{f}$ & $8.00 \mathrm{e}$ & $6.667 f$ & $5.33 \mathrm{~d}$ & $3.667 \mathrm{c}$ & 7.78 & 13 \\
\hline OK 285 & $27.33 \mathrm{ab}$ & $24.33 \mathrm{ab}$ & $22.67 \mathrm{a}$ & $21.67 \mathrm{a}$ & $16.67 \mathrm{ab}$ & $14.00 \mathrm{a}$ & 19.86 & 1 \\
\hline $\mathrm{OkraF}_{1}$ Green Soft & $17.67 \mathrm{cde}$ & 19.33abcd & $14.67 \mathrm{bcd}$ & 11.33de & $12.00 \mathrm{abc}$ & $9.333 \mathrm{ab}$ & 14.05 & 10 \\
\hline $\mathrm{F}_{1}$ Hybrid Fresh Power & $25.67 \mathrm{abc}$ & $22.67 \mathrm{abc}$ & $18.67 \mathrm{abc}$ & $19.00 \mathrm{a}$ & $14.67 \mathrm{abc}$ & $14.33 \mathrm{a}$ & 19.16 & 4 \\
\hline $\mathrm{F}_{1}$ Hybrid Sarosh 3 & $18.33 \mathrm{cde}$ & 18.33abcd & $16.00 \mathrm{bcd}$ & $13.33 \mathrm{~cd}$ & $10.33 \mathrm{bcd}$ & $12.00 \mathrm{ab}$ & 14.72 & 6 \\
\hline Arka Anamika & $14.67 \mathrm{def}$ & $11.33 \mathrm{def}$ & $10.67 \mathrm{de}$ & $7.333 \mathrm{ef}$ & $8.667 \mathrm{~cd}$ & $6.67 b c$ & 9.88 & 12 \\
\hline Okra Nabil & $30.33 \mathrm{a}$ & $26.33 \mathrm{a}$ & $22.33 \mathrm{a}$ & $18.33 \mathrm{ab}$ & $17.67 \mathrm{a}$ & $14.67 \mathrm{a}$ & 21.11 & 3 \\
\hline BARI-1 (Samrat) & $18.67 \mathrm{cde}$ & 19.00cde & $14.33 \mathrm{bcd}$ & $12.33 \mathrm{~d}$ & $10.33 \mathrm{bcd}$ & $10.67 \mathrm{ab}$ & 14.22 & 9 \\
\hline Hybrid Chamak & $9.00 \mathrm{f}$ & $10.67 \mathrm{ef}$ & $7.00 \mathrm{e}$ & 7.667ef & $5.333 d$ & $6.667 \mathrm{bc}$ & 7.72 & 14 \\
\hline Local variety & 23.33abcd & $22.67 \mathrm{abc}$ & $17.33 \mathrm{abc}$ & 17.33abc & $16.33 \mathrm{ab}$ & $13.33 \mathrm{a}$ & 18.38 & 5 \\
\hline $\operatorname{LSD}_{(0.05)}$ & 7.803 & 7.333 & 4.934 & 4.142 & 5.725 & 5.113 & - & \\
\hline $\mathrm{CV}(\%)$ & 22.89 & 23.74 & 19.11 & 17.93 & 28.26 & 28.50 & - & \\
\hline Level of significance & $* * *$ & $* * *$ & $* *$ & $* *$ & $* *$ & $* *$ & & \\
\hline
\end{tabular}

Different letters in a column indicate the significant $(\mathrm{p} \leq 0.05)$ difference among the mean number of nymphs

In case of cumulative mean, significantly the highest mean number of nymphs per plant was recorded in Okra Nabil (21.11) followed by Hybrid Okra (MDR) (20.11), OK 285 (19.86), $F_{1}$ Hybrid Fresh Power (19.16) and Local variety (18.38) which indicated their highest preference to jassid. On the other hand, the lowest cumulative mean number of nymphs per plant was found on the plants of three varieties viz. Hybrid Chamak (7.73) Kolatia (7.77) and Arka Anamika (9.89) which were least preferred by the jassid. It was also observed that six varieties such as Okra $F_{1}$ Green Star 33 (14.61), BARI-1 (Samrat) (14.22), $F_{1}$ Tamanna (13.72), $F_{1}$ Hybrid Sarosh 3 (14.72), Hybrid Okra Gunyon (14.33), and Okra $F_{1}$ Green Soft (14.05) were moderately preferred by the jassid in the field with the average mean number of nymph per plant. So, the overall preference rank of jassid among 14 okra varieties was in the following descending order: Okra Nabil> Hybrid Okra (MDR) $>F_{1}$ Hybrid Fresh Power $>$ Local variety $>$ OK 285 $>$ Okra $F_{1}$ Green Star 33>BARI-1(Samrat)> Hybrid Okra Gunyon $>$ Okra $F_{1}$ Green Soft $>F_{1}$ Hybrid Sarosh 3> $F_{1}$ Tamanna>Arka Anamika> Kolatia >Hybrid Chamak. The present findings were similar with following report. Kumar and Singh (2002) studied the host preference of A. biguttula biguttula, on 22 okra cultivars in Faizabad, India and reported that pooled nymphal population of 
jassid was the lowest in Punjab Padmini (1.87), followed by DOV-91-4 (1.96) and Arka Anamika (1.98) and highest in Pusa Swani (3.77). This variation of jassid population among different okra varieties indicated the differences in their preference. In the present study it was observed that jassid preferred okra varieties differently in the field and the least preferred varieties were Hybrid Chamak, Arka Anamika and Kolatia but the most preferred varieties were Okra Nabil, Hybrid Okra (MDR) and $F_{1}$ Hybrid Fresh Power. Similar results were also found by some other researchers. Sharma and Sharma (1997) worked on the preference using the okra cultivars Pusa Swani, MR 10-1, MR 12, IC 7194 and observed that nymphal population of A. biguttula biguttula, remained significantly lower on IC 7194 and higher on Pusa Swani throughout growth period of crop which indicated its different degrees of resistance. They also reported the order of preference for okra cultivars tested, was Pusa Swani > MR 10-1> MR 12> IC 7194. Therefore, it was very clear from the present result and some other reports that nymph of jassid had differences of preference on various varieties of okra which were might be governed by the morpho-physiological and genetical characters of the plants of okra varieties.

\section{Mean number of adults per plant}

Similar to the eggs and nymph mean number of adult per plant varied significantly among the 14 varieties tested (Table 3). The mean number of adults per plant at 56 DAS was the lowest in case of variety Hybrid Chamak (9.000) followed by Kolatia (10.33) and Arka Anamika (13.33) but the highest number of adult was found in the variety Okra Nabil (33.00) followed by Hybrid Okra (MDR) (30.00), Local variety (27.00), $\mathrm{F}_{1}$ Hybrid Fresh Power (26.67), and OK 285 (24.33) (Table 3). The data also revealed that average mean number of adults per plant was found on the plants of six varieties such as BARI-1 Samrat (18.67), Okra $F_{1}$ Green Soft (17.67), Okra $F_{1}$ Green Star 33 (17.00), $F_{1}$ Tamanna (16.67), $F_{1}$ Hybrid Sarosh 3 (16.67), and Hybrid Okra Gunyon (16.00). Similarly, at 63 DAS the mean number of adults per plant was the lowest in case of variety Hybrid Chamak (8.00) followed by Kolatia (9.00) and Arka Anamika (12.33) but the highest number of adult per plant was found in the variety Okra Nabil (29.00) followed by Hybrid Okra (MDR) (25.33), OK 285 (21.00), $F_{1}$ Hybrid Fresh Power (23.33), and Local variety (23.33). The rest of the varieties were moderately preferred by jassid.

The mean number of adults per plant at 70 DAS was the lowest on the plants of variety Hybrid Chamak (7.33) and followed by Kolatia (7.67), and Arka Anamika (11.33) and the highest number was found in Okra Nabil (25.67) followed by OK 285 (22.67), Hybrid Okra (MDR) (22.33), F 1 Hybrid Fresh Power (18.33), and Local variety (17.6 7). It was also revealed that average mean numbers of adults were found on the plants of six other varieties. Similarly, at 77 DAS the mean number of adults per plant was the lowest in case of variety Kolatia (7.33) followed by Arka Anamika (8.33) and Hybrid Chamak (10.33). The highest number of adults per plant was found in the variety Okra Nabil (25.67) followed by $\mathrm{OK} 285$ (22.67), Hybrid Okra (MDR)(22.33), $F_{1}$ Hybrid Fresh Power (18.33) and Local variety (17.67). Rest of the varieties was moderately preferred by jassid.

The mean number of adults per plant at 84 DAS was the lowest in Hybrid Chamak (3.00) followed by Arka Anamika (4.00) and Kolatia (6.33) but the highest number was found in the variety Hybrid Okra (MDR) (14.33), OK 285 (16.33), $F_{1}$ Hybrid Fresh Power (17.33), Okra Nabil (18.67) and Local variety (15.67). Similarly, at 91 DAS the mean number of adults per plant was the lowest in case of variety Hybrid Chamak (1.33) followed by Arka Anamika ( 3.33), Kolatia (4.67). The highest number of adult per plant was found in the variety Okra Nabil (14.67) followed by Hybrid Okra (MDR) (14.33), $\mathrm{F}_{1}$ Hybrid Fresh Power (13.33), Local variety (13.33) and OK 285 (13.00).

In case of cumulative mean, significantly the highest number of adults were recorded in Okra Nabil (23.89) followed by Hybrid Okra (MDR) (21.22), F1 Hybrid Fresh Power (19.28), OK 285 ( 19.17) and Local variety (19.00) which indicated the highest reference of these varieties to jassid. But three varieties viz. Hybrid Chamak (6.49), Kolatia (7.55) and Arka Anamika (8.77) had significantly the lowest number of adult per plant which proved to be the least preference to jassid. The observation in rest of six varieties revealed average mean number of adult per plant on the varieties, Okra F1 Green Star 33 (13.89), BARI-1 (Samrat) (14.83), F1 Tamanna (13.38 ), Hybrid Okra Gunyon (13.72), F1 Hybrid Sarosh 3 (14.61), and Okra F1 Green Soft (13.16) which were moderately preferred by the jassid. So, the overall preference rank for okra jassid among 14 okra varieties was in the following descending order: Okra Nabil $>$ Hybrid Okra (MDR) >, F $F_{1}$ Hybrid Fresh Power $>$ Local variety>OK $285>$ Okra $F_{1}$ Green Star 33>BARI-1 Samrat $>F_{1}$ Tamanna $>$ Hybrid Okra Gunyon $>F_{1}$ Hybrid Sarosh $3>$ Okra F $_{1}$ Green Soft $>$ Arka Anamika $>$ Kolatia >Hybrid Chamak. From the present study Arka Anamika was found resistant to jassid with the least preference by the adult jassid which is partially supported by the report of Iqbal et al. (2008). They worked on 30 varieties of okra and observed that among these varieties Arka Anamika (1.81) was moderately resistant and Pusa Swani (3.32) was highly susceptible. Similarly, Khambete and Desai (1996) stated the varietal preference of adult jassid and reported that significantly lower preference of jassid was to the varieties Sel-a, Ankur 35, BO 1, Plon-44-13, Sel-3 and HOE 301. In another research Javed et al. (2016) tested five cultivars for resistance against jassid and reported that Arka Anamika and Ambika were the resistant and susceptible cultivars among tested cultivars. Similarly, Gul (1998) 
tested six varieties, viz. T-13, Rich green, Perking dwarf, Pusa Green, Climson spineless and Swat local against jassid, in okra and reported that all varieties were found susceptible with higher preference by the pest.

Table 3. Mean number of adults of okra jassid per plant on different okra varieties in the field

\begin{tabular}{|c|c|c|c|c|c|c|c|c|}
\hline \multirow[t]{2}{*}{ Variety } & \multicolumn{7}{|c|}{ No. of adults/plant } & \multirow[b]{2}{*}{ Rank } \\
\hline & 56 DAS & 63 DAS & 70 DAS & 77 DAS & 84 DAS & 91 DAS & $\begin{array}{c}\text { Cumulative } \\
\text { mean }\end{array}$ & \\
\hline Hybrid Okra (MDR) & $30.00 \mathrm{ab}$ & $25.33 \mathrm{ab}$ & $22.33 \mathrm{ab}$ & $19.00 \mathrm{ab}$ & $16.33 \mathrm{abc}$ & $14.33 \mathrm{a}$ & 21.22 & 2 \\
\hline $\mathrm{F}_{1}$ Tamanna & $16.67 \mathrm{ab}$ & $15.00 \mathrm{de}$ & $14.00 \mathrm{~cd}$ & $12.33 \mathrm{bcd}$ & $12.00 \mathrm{abc}$ & $10.33 \mathrm{abc}$ & 13.39 & 10 \\
\hline Hybrid Okra Gunyon & $16.00 \mathrm{de}$ & $15.67 \mathrm{de}$ & $15.00 \mathrm{~cd}$ & $14.33 \mathrm{bcd}$ & $9.00 \mathrm{defg}$ & $12.33 \mathrm{ab}$ & 13.72 & 9 \\
\hline $\mathrm{F}_{1}$ Green Star 33 & $17.00 \mathrm{de}$ & $15.67 \mathrm{de}$ & $16.00 \mathrm{~cd}$ & $13.67 \mathrm{bcd}$ & 10.33 bcdef & $10.67 \mathrm{abc}$ & 13.89 & 8 \\
\hline Kolatia & $10.33 \mathrm{f}$ & $9.00 \mathrm{f}$ & $7.667 \mathrm{e}$ & $7.333 \mathrm{~d}$ & $6.333 \mathrm{efg}$ & $4.667 \mathrm{~cd}$ & 7.55 & 13 \\
\hline OK 285 & $24.33 \mathrm{c}$ & $21.00 \mathrm{bcd}$ & $22.67 \mathrm{ab}$ & $17.67 \mathrm{ab}$ & $16.33 \mathrm{abc}$ & $13.00 \mathrm{ab}$ & 19.16 & 4 \\
\hline $\mathrm{F}_{1}$ Green Soft & $17.67 \mathrm{de}$ & $17.00 \mathrm{de}$ & $15.00 \mathrm{~cd}$ & $12.33 \mathrm{bcd}$ & $10.00 \mathrm{cdef}$ & $7.000 \mathrm{bcd}$ & 13.16 & 11 \\
\hline $\mathrm{F}_{1}$ Hybrid Fresh Power & $26.67 b c$ & $23.33 \mathrm{abc}$ & $18.33 \mathrm{bc}$ & $16.67 \mathrm{abc}$ & $17.33 \mathrm{ab}$ & $13.33 \mathrm{ab}$ & 19.27 & 3 \\
\hline $\mathrm{F}_{1}$ Hybrid Sarosh 3 & $16.67 \mathrm{de}$ & $17.33 \mathrm{cde}$ & $15.00 \mathrm{~cd}$ & $13.3 \mathrm{bcd}$ & $12.67 \mathrm{bcde}$ & $12.67 \mathrm{~b}$ & 14.61 & 7 \\
\hline Arka Anamika & $13.33 \mathrm{ef}$ & $12.33 \mathrm{ef}$ & $11.33 \mathrm{de}$ & $8.33 \mathrm{~d}$ & $4.00 \mathrm{fg}$ & $3.333 \mathrm{f}$ & 8.776 & 12 \\
\hline Okra Nabil & $33.00 \mathrm{a}$ & $29.00 \mathrm{a}$ & $25.67 \mathrm{a}$ & $22.33 \mathrm{a}$ & $18.67 \mathrm{a}$ & $14.67 \mathrm{a}$ & 23.89 & 1 \\
\hline BARI-1 (Samrat) & $18.67 d$ & $18.33 \mathrm{cde}$ & $13.33 \mathrm{~cd}$ & $16.00 \mathrm{abc}$ & 12.00abcde & $10.67 \mathrm{abc}$ & 14.83 & 6 \\
\hline Hybrid Chamak & $9.00 \mathrm{f}$ & $8.00 \mathrm{f}$ & $7.333 \mathrm{e}$ & $10.33 f$ & $3.00 \mathrm{~g}$ & $1.333 \mathrm{~d}$ & 6.50 & 14 \\
\hline Local variety & $27.00 \mathrm{bc}$ & $23.33 \mathrm{abc}$ & $17.67 \mathrm{bc}$ & $17 \mathrm{abc}$ & $15.67 \mathrm{abc}$ & $13.33 \mathrm{ab}$ & 19 & 5 \\
\hline $\operatorname{LSD}_{(0.05)}$ & 4.686 & 5.540 & 5.010 & 6.274 & 6.205 & 5.958 & - & \\
\hline CV $(\%)$ & 14.15 & 18.46 & 18.88 & 26.08 & 31.63 & 35.08 & & \\
\hline Level of significance & $* *$ & $* *$ & $* *$ & $* * *$ & $* * *$ & $* *$ & & \\
\hline
\end{tabular}

Different letters in a column indicate the significant $(\mathrm{p} \leq 0.05)$ difference among the mean number of adults

\section{Mean number of curl leaf per plant}

The mean number of curl leaf per plant was observed among 14 varieties at 77 DAS. The mean number of curl leaf per plant was the lowest in case of variety Hybrid Chamak (1.30) followed by Kolatia (2.00) and Arka Anamika (2.33). The highest number of curl leaf per plant was found in the variety Okra Nabil (6.30) followed by $\mathrm{F}_{1}$ Hybrid Fresh Power (5.33), Hybrid Okra (MDR) (5.00), Local variety (5.00) and OK 285 (4.3). The average mean number of curl leaf was observed on the plants of six varieties viz. Okra $F_{1}$ Green Star 33 (3.66), $F_{1}$ Hybrid Sarosh 3 (3.33), BARI-1 (Samrat) (3.33), Hybrid Okra Gunyon (3.30), Okra $\mathrm{F}_{1}$ Green Soft (3.00) and $\mathrm{F}_{1}$ Tamanna (3.00).

Table 4. Mean number of curl leaf per plant on different okra varieties in the field

\begin{tabular}{lc}
\hline Variety & Mean number of curl leaf/plant \\
\hline Hybrid Okra (MDR) & $5.00 \mathrm{abc}$ \\
Okra F ${ }_{1}$ Green Soft & $3.00 \mathrm{bcde}$ \\
Okra F Freen Star $33_{\mathrm{F}_{1} \text { Hybrid Sarosh } 3}$ & $3.60 \mathrm{bcd}$ \\
Kolatia & $3.00 \mathrm{bcde}$ \\
OK 285 & $2.00 \mathrm{de}$ \\
Hybrid Okra Gunyon & $4.20 \mathrm{abcd}$ \\
Okra Nabil & $3.30 \mathrm{bcde}$ \\
$\mathrm{F}_{1}$ Tamanna & $6.00 \mathrm{a}$ \\
Arka Anamika & $3.00 \mathrm{cde}$ \\
$\mathrm{F}_{1}$ Hybrid Fresh Power & $2.20 \mathrm{de}$ \\
BARI-1 (Samrat) & $5.00 \mathrm{ab}$ \\
Hybrid Chamak & $3.40 \mathrm{bcde}$ \\
Local variety & $1.00 \mathrm{e}$ \\
LSD & $5.00 \mathrm{abc}$ \\
CV $(\%)$ & 2.007 \\
Level of significance & 32.41 \\
\hline
\end{tabular}

Different letters in the column indicate the significant $(\mathrm{p} \leq 0.05)$ difference among the mean number of curl leaf
From the table it was clearly noticed that number of curl leaf per plant increased with the increase of susceptibility of the variety tested in the present study. Therefore, number of curl leaf of the plant found higher in variety Okra Nabil while lower number in variety Hybrid Chamak.

\section{Conclusion}

From the results it was found that the mean number of eggs, nymphs, adults and curled leaf per plant varied significantly among the 14 varieties tested. Based on these parameters the least preferred variety by the jassid was Hybrid Chamak followed by Kolatia and Arka Anamika. The most preferred variety was Hybrid Okra (MDR), Local variety, $F_{1}$ Hybrid Fresh Power and OK 285. Therefore, Hybrid Chamak, Kolatia and Arka Anamika might be used as resistant variety for ecofriendly management of jassid in the field.

\section{References}

Akintoye, H.A., Adebayo, A.G. and Aina, O.O. 2011. Growth and yield response of okra intercropped with live mulches. Asian J. Agric. Res. 5:146-153.

Arapitsas P. 2008. Identification and quantification of polyphenolic compounds from okra seeds and skins. Food Chem. 110(4):1041-1045

Bangladesh Bureau of Statistics (BBS). 2011. Year Book of agricultural statistics of Bangladesh. Ministry of Planning. Dhaka.

Dhandapani, N., Shelkar, U.R. and Murugan, M. 2003. Bio-intensive pest management (BIPM) in major vegetable crops: an Indian perspective. J. Food. Agric. Environ. 1( 2): 333-339.

Dilruba, S., Hasanuzzaman, M., Karim, R. and Nahar, K. 2009. Yield response of okra to different sowing time and application of growth hormones. J. Hortic. Sci. Ornamental Plants. 1:10-14. 
El-Tom, H.A. 1987. Integrated pest management for cotton in Bangladesh (Terminal Report). FAO/UNDP Cotton Improvement Program. Cotton Research Station, Rangpur, Bangladesh. 4p.

Gallun, R. L., Starks, K. J and Guthrie, W. D. 1975. Plant resistance to insects attacking cereals. Annu. Rev. Entomol. 20: 337

Gul, F. 1998. Evaluation of different insecticides and cultivars against jassid in okra. Sarhad J. Agric.14(4): 351-354.

Iqbal, J., Ashfaq, M., Hasan, M., Sagheer, M. and Nadeem, M. 2008. Influence of abiotic factors on population fluctuation of leaf hopper, Amrasca biguttula biguttula (Ishida) on Okra in Pakistan. J. Zool. 42(5): 615-621.

Javed, K., Rashid, M.A., Munawar, A., Hussain, K. and Javed, H. 2016. Varietal and physico-morphic resistance of okra cultivars against Amrasca biguttula biguttula (Homoptera: Cicadellidae). J. Entomol. Zool. Studies. 4(5):313-317.

Kahlon ,T. S., Chapman, M. H. and Smith, G. E. 2007. In vitro binding of bile acids by okra beets asparagus eggplant turnips green beans carrots and cauliflower. Food Chem. 103: 676-680.

Khambete, M.S. and Desai, B.D. 1996. Studies on the varietal resistance of okra to jassid and shoot and fruit borer. TVISNewslet. 1(2): 18-19.

Kochhar, S.L. 1986. "Tropical Crops" The Macmillan Press Ltd. New Delhi. Pp. 263-264.
Kumar M and Singh A K. 2002. Varietal resistance of okra against cotton jassid, Amrasca biguttula biguttula under field conditions. Ann. Pl. Prot. Sci. 10:381-383.

Rashid, M.M. 1999. Bibidhi shabji (Dheros), In: Shabji Biggan (In Bangla). 4: 66-71.

Saifullah, M. and Rabbani, M.G. 2009. Evaluation and characterization of okra (Abelmoschus esculentus . moench.) genotypes. SAARC J. Agric. 7: 92-99.

Sharma, G.N. and Sharma, P.D. 1997. Biology and development of cotton leafhopper, Amrasca biguttula biguttula (Ishida) on different genotype of okra (Abelmoschus esculentus (L.) Monech). Crop Res. Hisar .14(3): 487-492.

Singh J., Sohi A.S., Dhaliwal Z.S., Mann H.S. 1993. Comparative incidence of Helicoverpa armigera $\mathrm{Hb}$. and other pests on okra and sunflower intercrops in cotton under Punjab conditions. J. Insect Sci. 6:137-138.

Ullah, S., Javed, H. and Aziz, M.A. 2012. Role of physico-morphic characters of okra in jassid population. Department of Entomology, PMAS-Arid Agriculture University, Rawalpindi, Pakistan. J. Agric. Res. 50(2): 217-224.

Uthamasamy, S. 1986. Studies on the resistance in okra, Abelmoschus esculentus (L) Moench to the leafhopper, Amrasca devastans (Dist.). Tropi. Pest Manage. 32(2): 146-147. 